In cooperation with Northern Arizona University

Aggradation and Degradation of the Palisades Gully Network, 1996 to 2005, with Emphasis on the November 2004 High-Flow Experiment, Grand Canyon National Park, Arizona

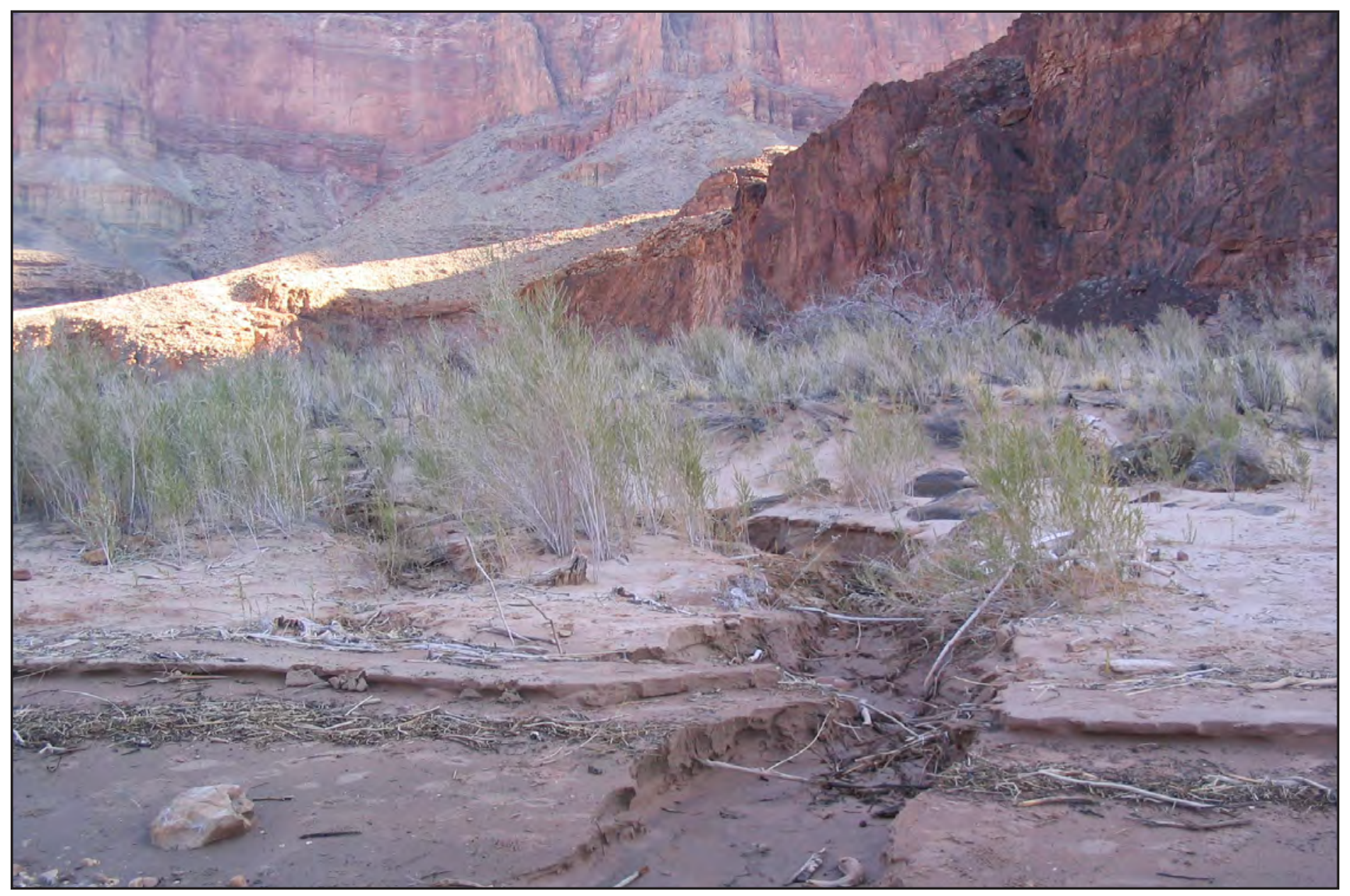

Open-File Report 2008-1264 
This page intentionally left blank 


\section{Aggradation and Degradation of the Palisades Gully Network, 1996 to 2005, with Emphasis on the November 2004 High-Flow Experiment, Grand Canyon National Park, Arizona}

By Joseph E. Hazel, Jr., Matt Kaplinski, Roderic A. Parnell, and Helen C. Fairley

Open-File Report 2008-1264 


\section{U.S. Department of the Interior DIRK KEMPTHORNE, Secretary}

\section{U.S. Geological Survey \\ Mark D. Myers, Director}

\section{U.S. Geological Survey, Reston, Virginia: 2008}

For product and ordering information:

World Wide Web: http://www.usgs.gov/pubprod

Telephone: 1-888-ASK-USGS

For more information on the USGS--the Federal source for science about the Earth, its natural and living resources, natural hazards, and the environment:

World Wide Web: http://www.usgs.gov

Telephone: 1-888-ASK-USGS

Any use of trade, product, or firm names is for descriptive purposes only and does not imply endorsement by the U.S. Government.

Although this report is in the public domain, permission must be secured from the individual copyright owners to reproduce any copyrighted materials contained within this report.

Suggested citation:

Hazel, Joseph E., Jr., Kaplinski, Matt, Parnell, Roderic A., and Fairley, Helen C., 2008, Aggradation and degradation of the Palisades gully network, 1996 to 2005, with emphasis on the November 2004 high-flow experiment, Grand Canyon National Park, Arizona: U.S. Geological Survey Open-File Report 2008-1264, 14 p. 


\section{Contents}



\section{Figures}

1. Maps showing the location of study area ......................................................................

2. Aerial photograph taken in May 2002 showing the Palisades gully network...................3

3. Photographs of the Palisades gully network taken on November 17, 2004 ......................4

4. Longitudinal gully profiles showing the stage elevations reached by flows of $227 \mathrm{~m}^{3} / \mathrm{s}$ and $1,161 \mathrm{~m}^{3} / \mathrm{s}$ and the mouth area discussed in the text ..................................................

5. Palisades drainage network topography constructed from the point data collected on November 20, 2004.........................................................................................................

6. Pre- and post-flood centerline longitudinal profiles of the south gully mouth..................8

7. The south gully mouth viewed from the terminus at the Colorado River ...........................8

8. Pre- and post-flood changes along the centerline longitudinal profile of the south



9. South gully mouth time series constructed from the average centerline elevation data

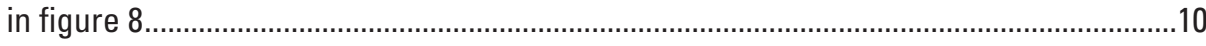



11. Cross sections established by the National Park Service in January 1998....................12

\section{Tables}

1. Topographic surveys conducted at the Palisades drainage network ...............................6

2. Volume of sediment scoured and filled at the south gully ................................................

3. Lower and middle section gully slope gradients, February 1998-May 2005 ...................11 


\title{
Aggradation and Degradation of the Palisades Gully Network, 1996 to 2005, with Emphasis on the November 2004 High-Flow Experiment, Grand Canyon National Park, Arizona
}

\author{
By Joseph E. Hazel, Jr. ${ }^{1}$, Matt Kaplinski ${ }^{1}$, Roderic A. Parnell ${ }^{1}$, and Helen C. Fairley ${ }^{2}$
}

\section{Abstract}

This study examines a large drainage network incised into alluvial terraces located along the Colorado River downstream of Palisades Creek in Grand Canyon National Park, Ariz. Gully erosion in the drainage affects archaeological sites found on the wide, relatively flat alluvial terraces. In 1996, 7-d release of 1,274 cubic meters per second of water from Glen Canyon Dam, known as a controlled flood, deposited finegrained sediment — sand, silt, and clay — in the mouth of the network's largest gully, informally known as south gully. The deposit persisted for several years, but the drainage network steepened in the downstream reaches between 1999 and 2004. A high-flow experiment similar to the 1996 controlled flood was conducted in November 2004. The 2004 experiment was of a lower magnitude and shorter duration compared to the 1996 controlled flood. Topographic surveys were made in the field before, immediately after, and 6 months following the November 2004 experiment, and these measurements were compared to those made in 1996 and in other years. Similar to the response in 1996, fine-grained sediment was deposited in the mouth of the south gully and this mass was largely retained during the 6 months following the 2004 event. The magnitude of deposition in 2004 was nearly two times greater than that resulting from the 1996 controlled flood. We attribute this marked difference to increased accommodation space for deposition in the gully mouth, which was more deeply eroded in 2004 than it was in 1996. The second of the two primary gullies found within the Palisades gully network, the north gully, was largely unaffected by either high flow. Between 1996 and 2005, erosion was primarily confined to the lower reach of the south gully, while the upper reach remained relatively stable. The available data suggest that local base-level changes in the south gully mouth were not linked to the stability of the upstream gully reach. It could

\footnotetext{
${ }^{1}$ Northern Arizona University, Department of Geology, Flagstaff, Ariz.

${ }^{2}$ U.S. Geological Survey, Southwest Biological Science Center, Flagstaff, Ariz.
}

not be determined whether temporary base-level increases or maintenance of erosion-control structures were causal factors in limiting erosion in the upstream reaches of the drainage network.

\section{Introduction}

This study examines topographic changes within a large drainage network that has incised alluvial terraces located along the Colorado River downstream of Palisades Creek in eastern Grand Canyon National Park, Ariz. (fig. 1). This area is known as the Palisades gully network. Prehistoric archaeological sites associated with these terraces (Fairley and others, 1994) are being affected by gully incision during intense, localized rainfall events and, to a lesser extent, by aeolian deflation and visitor impacts (Leap and others, 2000; Pederson and others, 2003, 2006; Fairley, 2003). Increased erosion has been linked to a period of more intense precipitation during the mid1970s and to the presence and operation of Glen Canyon Dam (Hereford and others, 1993; Thompson and Potochnik, 2000). Closure of Glen Canyon Dam in 1963 altered the downstream hydrology of the Colorado River by cutting off the upstream sediment supply and eliminating flood flows; these changes have possibly affected the preservation potential of archeological sites (Draut and others, 2005).

The Operation of Glen Canyon Dam Final Environmental Impact Statement included the testing of occasional high-flow releases from Glen Canyon Dam to redistribute channel-stored sediment to the banks of the Colorado River (U.S. Department of Interior, 1995). The deposition of sediment in gully mouths, which would potentially lessen or slow incision rates and thus reduce impacts to archaeological sites, was among one of the possible benefits thought to derive from redistributing sand using high-flow releases. The first high-flow release test was a 7-d release of 1,274 cubic meters per second $\left(\mathrm{m}^{3} / \mathrm{s}\right)$ of water from Glen Canyon Dam from March 26 to April 2, 1996 (hereafter 1996 controlled flood; Webb and others, 1999). Topographic mapping of the Palisades drainage network before and after the 1996 controlled flood indicated that sediment was 
$\boldsymbol{A}$



$\boldsymbol{B}$

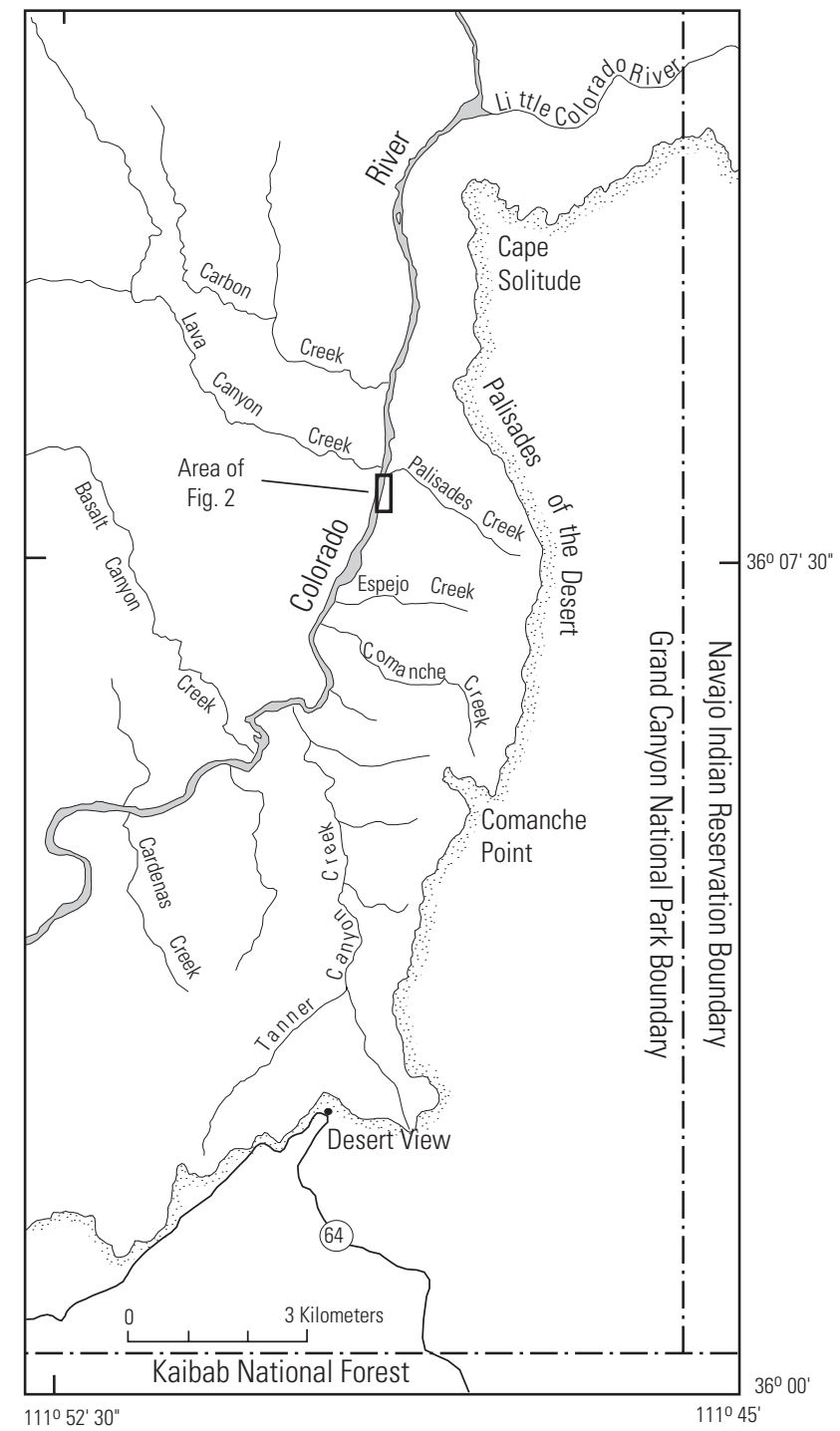

Figure 1. Maps showing the location of study area. $A$, Location map of study area within Grand Canyon National Park, Ariz. B, Location of Palisades gully network in eastern Grand Canyon National Park, Ariz. deposited in the larger of the two main gullies (Yeatts, 1996). Repeat surveys in the years following the 1996 controlled flood demonstrated that the deposit remained largely intact as late as 1999 (Yeatts, 1998; Hazel and others, 2000); however, renewed incision, knickpoint development, and widening were observed in 2002 (Pederson and others, 2003).

In the present study, we surveyed the Palisades gully network immediately before, 2 weeks after, and 6 mo after a November 2004 high-flow experiment (HFE). The experiment began on Sunday, November 21, 2004, when the Bureau of Reclamation opened the bypass tubes of Glen Canyon Dam for $90 \mathrm{~h}$. The peak high flows ran for $2.5 \mathrm{~d}(60 \mathrm{~h})$ at about $1,160 \mathrm{~m}^{3} / \mathrm{s}$. Similar to the 1996 controlled flood, the 2004 experiment was designed to redistribute new tributarysupplied sediment to the channel margins (Topping and others, 2006). We compare the data collected for the 2004 experiment with similar surveys conducted before and after the 1996 controlled flood and in other years to describe gully changes over a 9-yr period. The accuracy and utility of conventional total station ground surveys for change detection of gully erosion is also discussed.

\section{Physical Setting}

The study site is located at river mile 66.1 (66.1 river miles downstream from Lees Ferry, Ariz.) on the left bank (as viewed in a downstream direction) of the Colorado River in easternmost Grand Canyon, Ariz. (fig. 2). This area is within the "Furnace Flats" geomorphic reach of the Colorado River, as defined by Schmidt and Graf (1990). The Furnace Flats reach is characterized by a relatively wide, shallow channel. Bedrock at river level is the Precambrian Dox Formation and overlying Cardenas Basalt, and cemented Quaternary gravels (Huntoon and others, 1986). The drainage network is located on the downstream side of a large, low-gradient debris fan present at the mouth of Palisades Creek (Hereford and others, 1993).

The drainage network is actively eroding surficial deposits that consist of fluvial-derived fine-grained sediment, locally interbedded with aeolian sand and gravelly colluvium (fig. $3 A$ ). Hereford and others (1993) mapped four extensive terrace deposits at the site that date from before A.D. 950 to slightly before 1890, based on archaeological artifacts and radiocarbon ages (Hereford, 1996; Hereford and others, 1996). Largely inactive aeolian dunes are located adjacent to and on top of the fluvial terraces described by Hereford and others (1993). The dune field is bordered at the eastern margin by ponded, playa-like deposits that are partly composed of slope wash from the nearby Dox Formation (fig. $3 B$ ). Aeolian deposits are closely associated or interbedded with the fluvial and ponded deposits (Draut and others, 2005). Vegetation is relatively sparse and consists of a small number of tamarisk (Tamarix ramosissima) and arrowweed (Pluchea sericea) bordering the river margin; mesquite trees (Prosopis glandulosa), grasses, and cryptogamic crust are present elsewhere (appendix F in Pederson and others, 2003). 


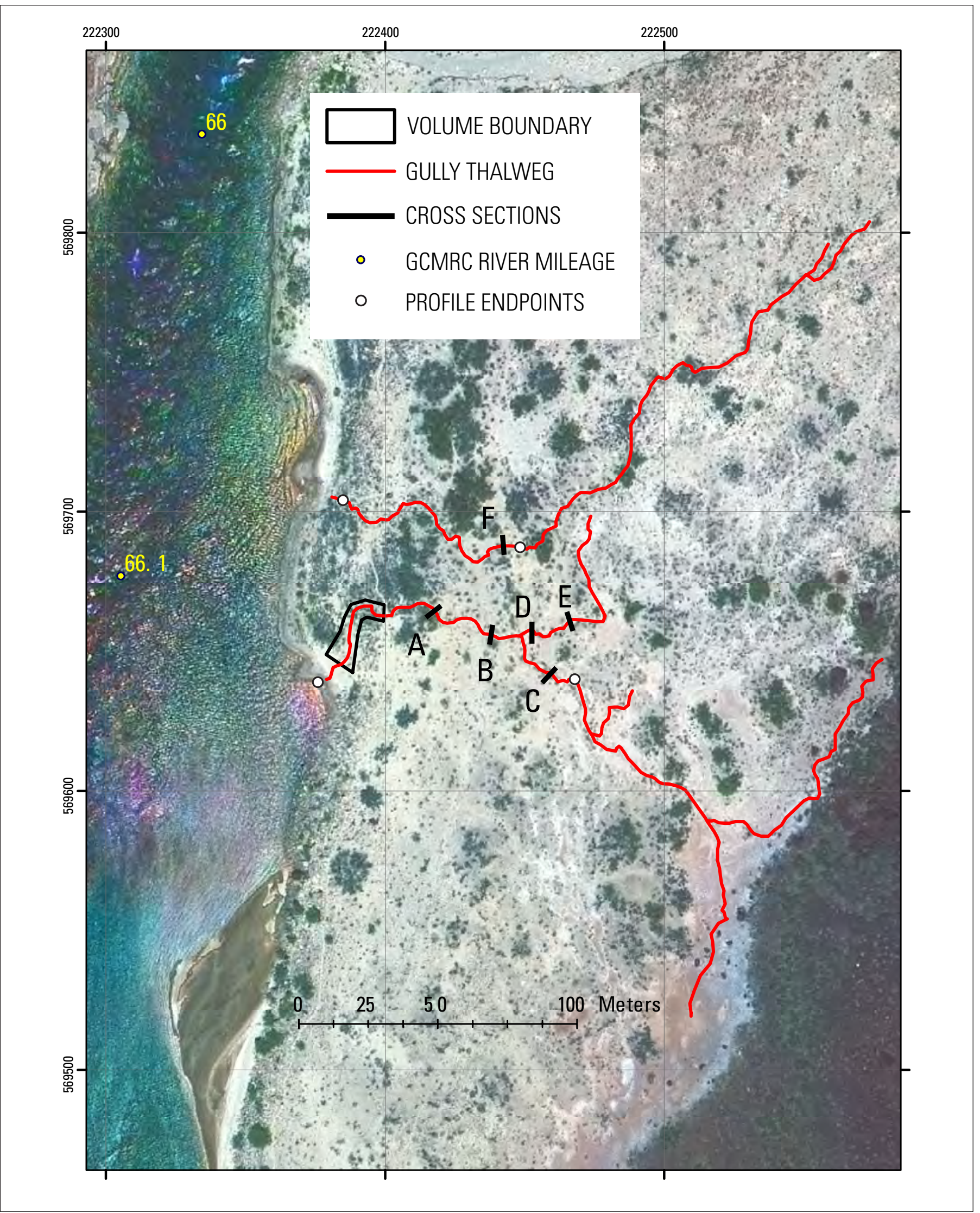

Figure 2. Aerial photograph taken in May 2002 showing the Palisades gully network. Colorado River discharge is approximately 226 $\mathrm{m}^{3} / \mathrm{s}$ and flow is from top to bottom of the photograph. Location is shown on figure 1. 

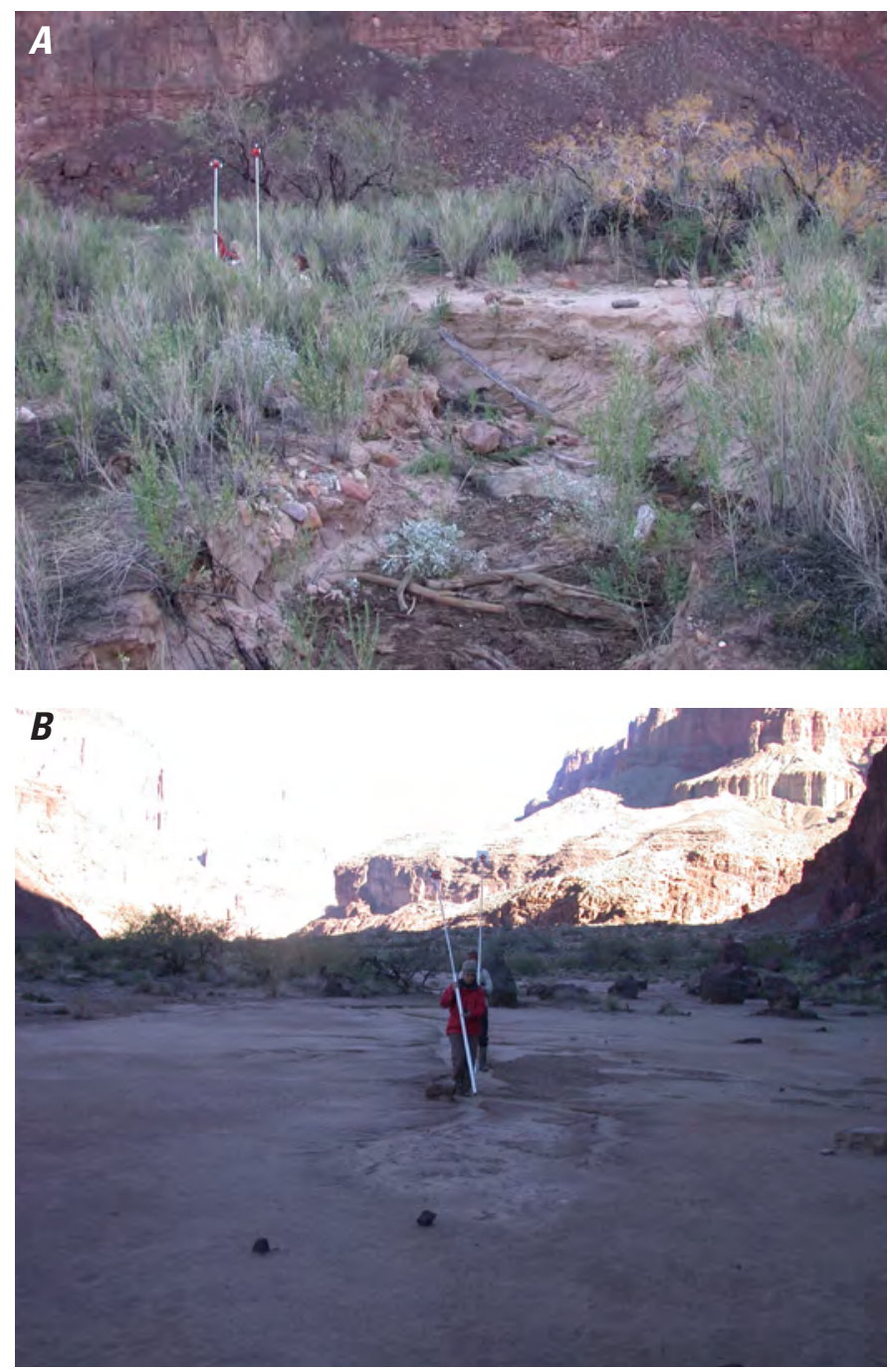

Figure 3. Photographs of the Palisades gully network taken on November 17, 2004. $A$, The south gully as viewed toward the playa catchment area. The Cardenas Basalt and a talus slope in background form the distal margin of the catchment area. $B$, The unvegetated playa catchment at the eastern margin of the Palisades area as viewed to the north. Photographs by David Topping, U.S. Geological Survey.

At topographic levels adjacent to the river, separation and reattachment bars are deposited in a large eddy (Schmidt and Graf, 1990). The reattachment bar is located downstream from the drainage network and is exposed at lower flows (fig. 2). Historic oblique and aerial photographs of the area show that these sand deposits were considerably larger in the predam era (Grams and Schmidt, 1999). The upper terraces at the site were interpreted by Hereford (1996) to have been deposited in overbank channels by flows in excess of 2,700 $\mathrm{m}^{3} / \mathrm{s}$. Driftwood elevation surveys and sedimentological analyses suggest the existence of an expansive eddy with upstream-directed flow during floods of $2,700 \mathrm{~m}^{3} / \mathrm{s}$ or greater (Draut and others, 2005).
The drainage network consists of two adjacent gullies, with numerous subsidiary channels (fig. 2). The local catchment is large (about 2 ha) and drains from the playa-dune complex on top of the highest terrace and from the southern margin of the Palisades debris fan (Hereford, 1996; Pederson and others, 2003). Terrace incision appears to have begun sometime after 1890; erosion increased dramatically between 1973 and 1984 (Hereford and others, 1993). By 1980, the drainage network extended across the dunes to the Colorado River (Thompson and Potochnik, 2000).

The two primary gullies in the network are informally named north and south, respectively, following the convention of Pederson and others (2003). The north gully is the shorter and steeper of the two gullies (fig. 4). As of May 2005, the north gully mouth debouched to the Colorado River at an elevation reached by a flow of about $800 \mathrm{~m}^{3} / \mathrm{s}$. The south gully was incised more deeply and entered the river at an elevation reached by a flow of about $300 \mathrm{~m}^{3} / \mathrm{s}$. The north gully was less than $0.75 \mathrm{~m}$ deep along its entire length, whereas the south gully had better defined walls and was 1.0-1.5 m deep along much of its length (fig. 5). The two gullies dropped $5.2 \mathrm{~m}$ and $5.7 \mathrm{~m}$ over lengths of $103 \mathrm{~m}$ and $212 \mathrm{~m}$ (0.051 and 0.027 slope gradient), respectively. Both gullies have been the focus of remedial stabilization efforts by the National Park Service; approximately 80 erosion-control structures composed of rock and brush check dams were built in 1995 from the head of the catchment area to the junction with the Colorado River (Leap and Coder, 1995). The check dams were periodically maintained or rebuilt into rock linings to armor the channel and banks in February 1997, February 1998, October 2000, April 2000, March 2003, March 2004, and March 2005 (Dierker and Leap, 2006).

\section{Methods}

Topographic changes were measured by field survey with electronic (optical) total stations. The mapping was focused on the area between the edge of the river and the playa area to an elevation reached by flows of about $4,500 \mathrm{~m}^{3} / \mathrm{s}$ (table 1). In general, field surveys were conducted by collecting ground points along break lines to define the edges and bottom thalweg of each gully. During the pre- and post-2004 HFE surveys, other areas were covered with individual points so that regular point spacing encompassed the entire site. Because of logistical constraints, the May 13, 2005, survey focused only on the gullies. The point density required for change detection depends on gully complexity. As a result, as many as 1,500 ground points were collected during each survey. This typically corresponded to a point density of one point per 3-5 $\mathrm{m}^{2}$ for the entire site, with a greater density of one point per $0.75 \mathrm{~m}^{2}$ concentrated in the gullies. The point data accuracy is on the order of $+0.1 \mathrm{~m}$ horizontally and $+0.05 \mathrm{~m}$ vertically. Survey accuracy in the field was maintained by horizontal and vertical checks of positional error between known reference points in the Grand Canyon Monitoring and Research Center's 


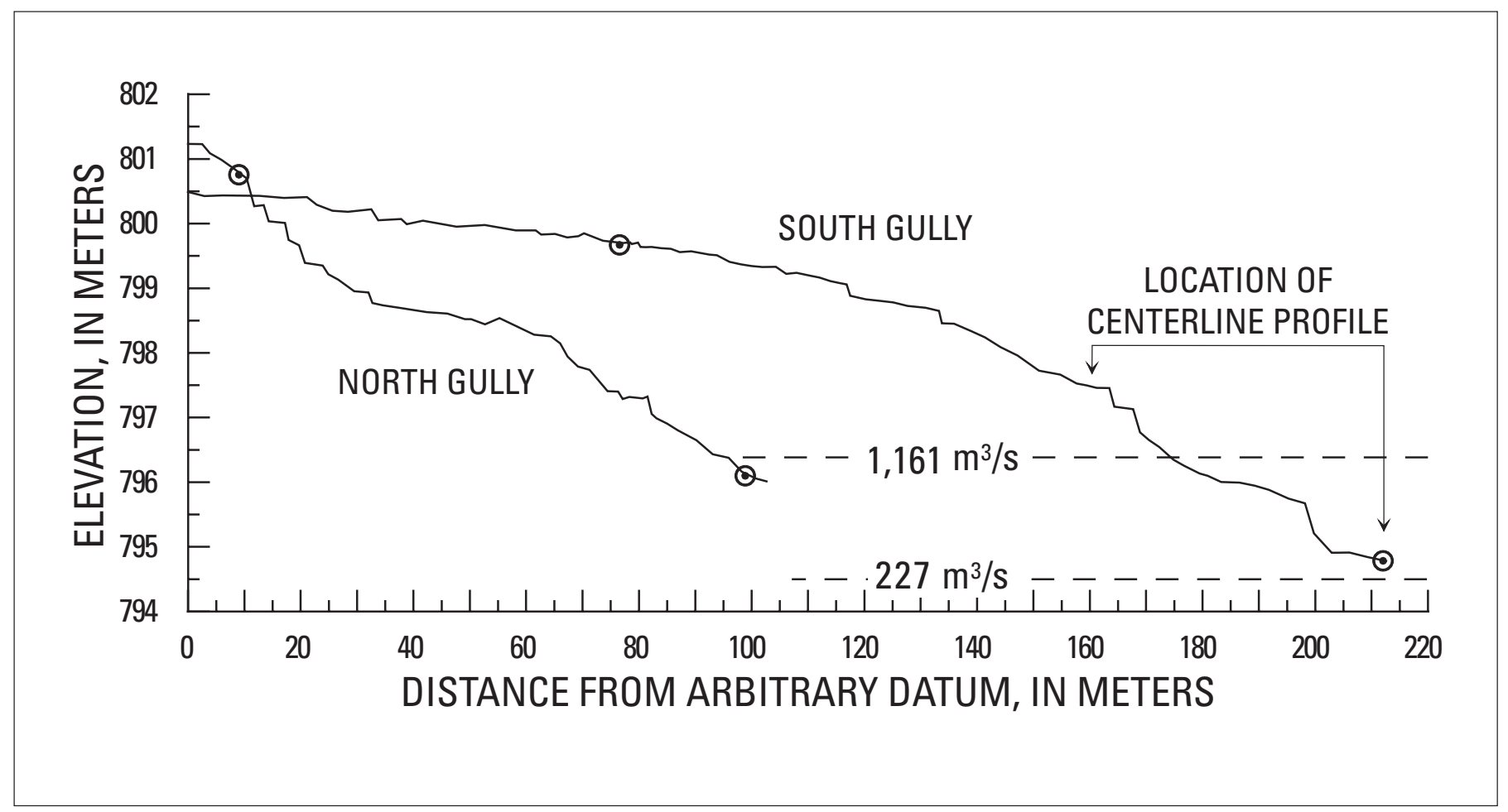

Figure 4. Longitudinal gully profiles showing the stage elevations reached by flows of $227 \mathrm{~m}^{3} / \mathrm{s}$ and $1,161 \mathrm{~m}^{3} / \mathrm{s}$ and the mouth area discussed in the text; the symbols indicate normalized profile endpoint locations. Note that the $1,161 \mathrm{~m}^{3} / \mathrm{s}$ discharge of the 2004 highflow experiment was insufficient to inundate the north gully mouth.

control network, an Arizona State Plane Coordinate System, 1983, Arizona Central Zone (0202) grid. Previous surveys collected by other researchers were also adjusted to this common datum. The historical surveys differ in the extent and types of data collected, varying from strictly thalweg profiles to complete topographic surveys of varying coverage (table 1).

Digital elevation models (DEMs) were created from surveys where survey extent allowed using surface modeling software (fig. 5). The DEMs were used to calculate volume changes and to delineate a channel centerline along equally spaced $0.2-\mathrm{m}$ distances in the south gully mouth between the 566 and $1,274 \mathrm{~m}^{3} / \mathrm{s}$ stage elevations. However, it is difficult to account for channel sinuosity with this method, and elevation errors are introduced with increasing gully length and convexity. Pederson and others (2003) developed a technique, which was adopted by this study, to compare longitudinal gully profiles by normalizing points collected along the gully thalweg between two fixed endpoints. The endpoint locations are shown in figures 2 and 4 . Neither centerline method nor the normalized alternative method is "noise free," and considerable variation is introduced to the profile depending on how the check dams and thalweg were defined and surveyed by different researchers. The centerline method is less subjective than the normalized alternative, which entails visually selecting points in the middle of the channel to represent the centerline.

\section{Results}

\section{Changes Detected as a Result of the 2004 High- Flow Experiment}

The 2004 HFE considerably modified the Palisades gully network by depositing sediment at lower nearshore elevations, infilling the south gully mouth, and eroding the lowermost downstream terrace margin. The north gully was largely unaffected by the 2004 event because the inundation depth at the gully mouth was less than $0.40 \mathrm{~m}$ (fig. 4). In contrast, the south gully was inundated to a maximum water depth of about $1.75 \mathrm{~m}$.

Infilling of the south gully resulted in deposition of 24.7 $\mathrm{m}^{3}$ of fine-grained sediment (table 2). Changes along the length of the lower reach of the south gully (between approximately 566 and $1161 \mathrm{~m}^{3} / \mathrm{s}$ stage elevation) are shown in figure 6 . The depth of fill was greatest at or near the gully mouth. The lowermost knickpoint, which was about $0.4 \mathrm{~m}$ high and 
Table 1. Topographic surveys conducted at the Palisades drainage network.

\begin{tabular}{|c|c|c|c|}
\hline Survey Date & Source & Survey Description' & $\begin{array}{l}\text { Profile Point Density }{ }^{2} \\
\text { (pts/m) }\end{array}$ \\
\hline 2-17-1996 & Yeatts, 1996 & Site topography up to $1,700 \mathrm{~m}^{3} / \mathrm{s}$ & $\mathrm{NC}$ \\
\hline $5-12-1996$ & Yeatts, 1996 & Site topography up to $1,700 \mathrm{~m}^{3} / \mathrm{s}$ & $\mathrm{NC}$ \\
\hline 4-22-1997 & Yeatts, 1998 & Site topography up to $1,700 \mathrm{~m}^{3} / \mathrm{s}$ & $\mathrm{NC}$ \\
\hline 2-28-1998 & $\begin{array}{l}\text { Grand Canyon National Park, K. Kohl, U.S. } \\
\text { Geological Survey, written commun., } 2006\end{array}$ & Thalwegs, cross sections, and check dams & 0.40 \\
\hline 10-14-1998 & Hazel and others, 2000 & Site topography up to $2,000 \mathrm{~m}^{3} / \mathrm{s}$ & 0.39 \\
\hline 10-7-1999 & Hazel and others, 2000 & Site topography up to $2,000 \mathrm{~m}^{3} / \mathrm{s}$ & 0.59 \\
\hline $1-6-2002$ & Pederson and others, 2003 & Thalweg profiles and check dams & 0.55 \\
\hline $9-27-2002$ & Pederson and others, 2003 & Thalweg profiles and check dams & 1.02 \\
\hline $11-11-2003$ & $\begin{array}{l}\text { K. Brown, U.S. Geological Survey, written } \\
\text { commun., } 2006\end{array}$ & Thalweg profiles & 0.37 \\
\hline $5-12-2004$ & Draut and others, 2005 & Thalweg profiles & 0.39 \\
\hline $11-20-2004$ & This study & Site topography up to $4,500 \mathrm{~m}^{3} / \mathrm{s}$ & 0.52 \\
\hline $12-10-2004$ & This study & Site topography up to $4,500 \mathrm{~m}^{3} / \mathrm{s}$ & 0.42 \\
\hline $5-13-2005$ & This study & Site topography up to $4,500 \mathrm{~m} 3 / \mathrm{s}$ & 0.43 \\
\hline
\end{tabular}

${ }^{1}$ Discharge elevation determined from a stage-discharge relation partly based on surveyed elevations of driftwood logs inferred to represent historical flood strandlines (Draut and others, 2005)

${ }^{2} \mathrm{NC}$ denotes that the data were not collected

capped by a 0.2 -m-thick layer of silt and clay, was buried by nearly $1 \mathrm{~m}$ of new sediment (fig. $7 A$ ). Erosion and bank retreat at the southeast margin of the gully wall, near the edge of the lowermost terrace, resulted in widening of the gully mouth (fig. $7 B$ ). About $12.0 \mathrm{~m}^{3}$ of material was eroded from these areas, but the net change was positive (table 2). Infilling of the south gully was substantially greater in 2004 than infilling observed in 1996 because the gully mouth was considerably larger in 2004 (Increased accommodation space is discussed in a following section.).

\section{South Gully Changes between December 2004 and May 2005}

The sediment mass deposited in the south gully mouth was still largely intact 6 mo after the 2004 HFE; however, some minor reworking of the gully bottom was detected. Between December 2004 and May 2005, 3 mo of large daily release fluctuations $-425 \mathrm{~m}^{3} / \mathrm{s}$ fluctuations with daily peaks of $566 \mathrm{~m}^{3} / \mathrm{s}$ - occurred. These dam releases had little effect on the mouth of the south gully (fig. 6). However, $8.4 \mathrm{~m}^{3}$ of scour in the lower reach of the south gully, coupled with 3.8 $\mathrm{m}^{3}$ of redeposition, resulted in a net erosion of $4.6 \mathrm{~m}^{3}$ of the flood-emplaced sediment (table 2). There was little evidence of substantial incision and no evidence to suggest that water had been flowing in the gullies during the interval between surveys. The weather station on river left in the Palisades area indicates that the largest daily precipitation amount, which occurred on March 24, 2005, was about $13.7 \mathrm{~mm}$ (Draut and Rubin, 2006) - an amount we speculate did not result in surface flow in the drainage network. Therefore, we presume the erosion was likely a result of wind deflation rather than renewed gullying. Wind velocities capable of entraining fine sediment at the site were recorded in late December 2004, early January 2005, and during the 2005 spring months (Draut and Rubin, 2005, 2006).

\section{Comparison of the 1996 Controlled Flood and the 2004 High-Flow Experiment}

The channel centerline method was used to compare the effects of the 1996 controlled flood with those of the 2004 HFE, because detailed thalweg profiles were not measured in 1996 (table 1). In order to directly compare a longitudinal profile in the south gully mouth, the centerline values interpolated from the DEMs were subtracted from the pre-1996 flood values, which was arbitrarily defined as the baseline condition (fig. 8). The points were then averaged to produce a time series of base-level change within the gully mouth (fig. 9).

Deposition in the south gully as a result of the 2004 HFE was nearly two times greater than that resulting from the 1996 controlled flood (table 2), even though the peak stage reached by the lower magnitude $2004 \mathrm{HFE}$ was about $0.20 \mathrm{~m}$ lower in elevation. For the south gully, the average gully bottom eleva- 


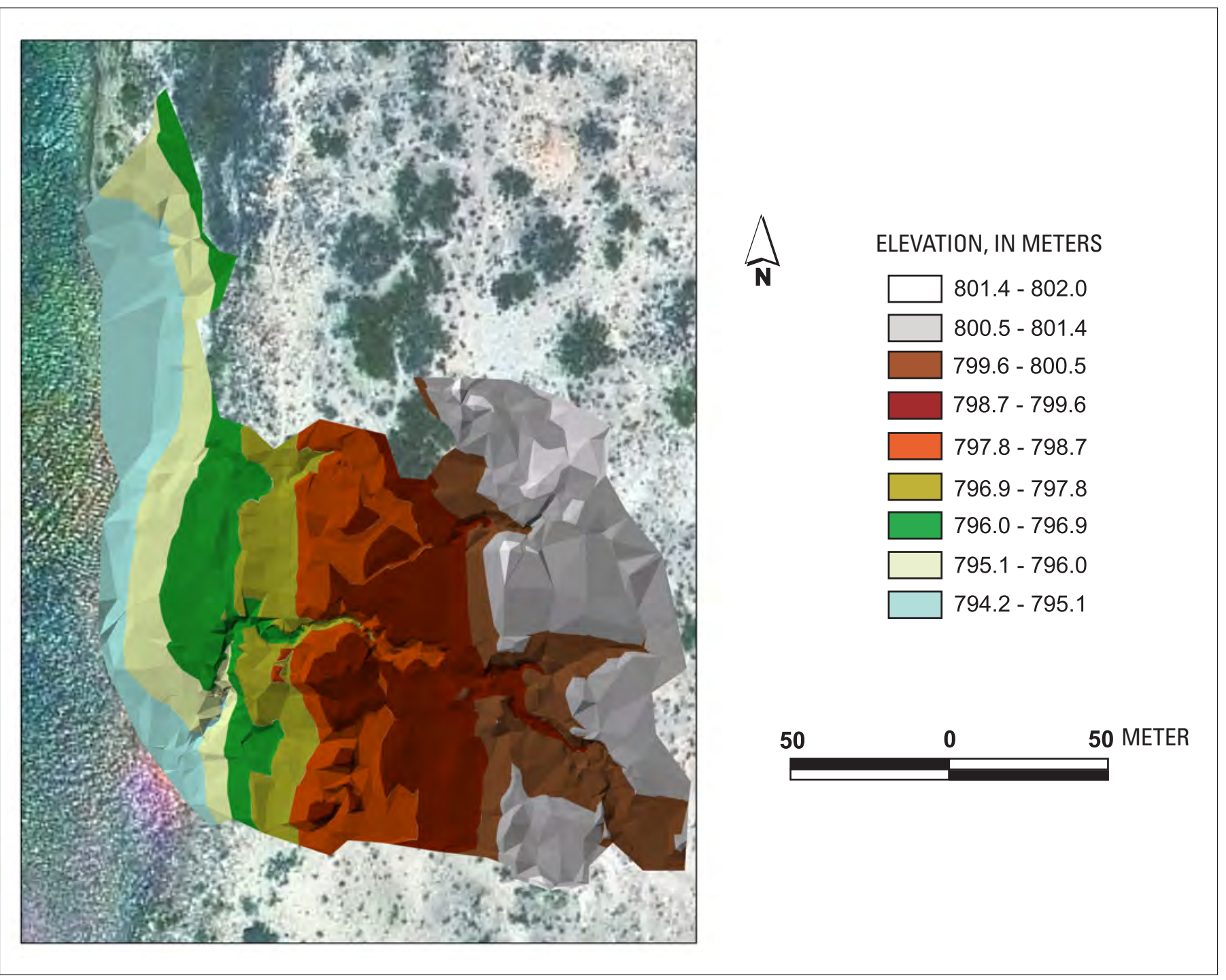

Figure 5. Palisades drainage network topography constructed from the point data collected on November 20, 2004.

Table 2. Volume of sediment scoured and filled at the south gully.

\begin{tabular}{lcccc}
\hline \multicolumn{1}{c}{ Survey Dates } & $\begin{array}{c}\text { Comparison interval } \\
\text { (Days) }\end{array}$ & Scour $\left(\mathbf{m}^{3}\right)$ & Fill $\left(\mathbf{m}^{3}\right)$ & Net change $\left(\mathbf{m}^{3}\right)$ \\
\hline $\begin{array}{l}\text { 2-17-1996 to 5-12-1996 (1996 Controlled } \\
\quad \text { Flood) }\end{array}$ & 85 & 6.5 & 10.0 & 3.5 \\
10-07-1999 to 11-20-04 & 1,891 & -66.5 & 2.7 & -63.8 \\
11-20-2004 to 12-10-2004 & 20 & -12.0 & 24.7 & 12.7 \\
(2004 High-Flow Experiment) & & & & -4.6 \\
12-10-2004 to 5-13-2005 & 154 & -8.4 & 3.8 & -52.7 \\
2-17-1996 to 12-10-2004 & 3,216 & -54.8 & 2.1 & \\
\hline
\end{tabular}




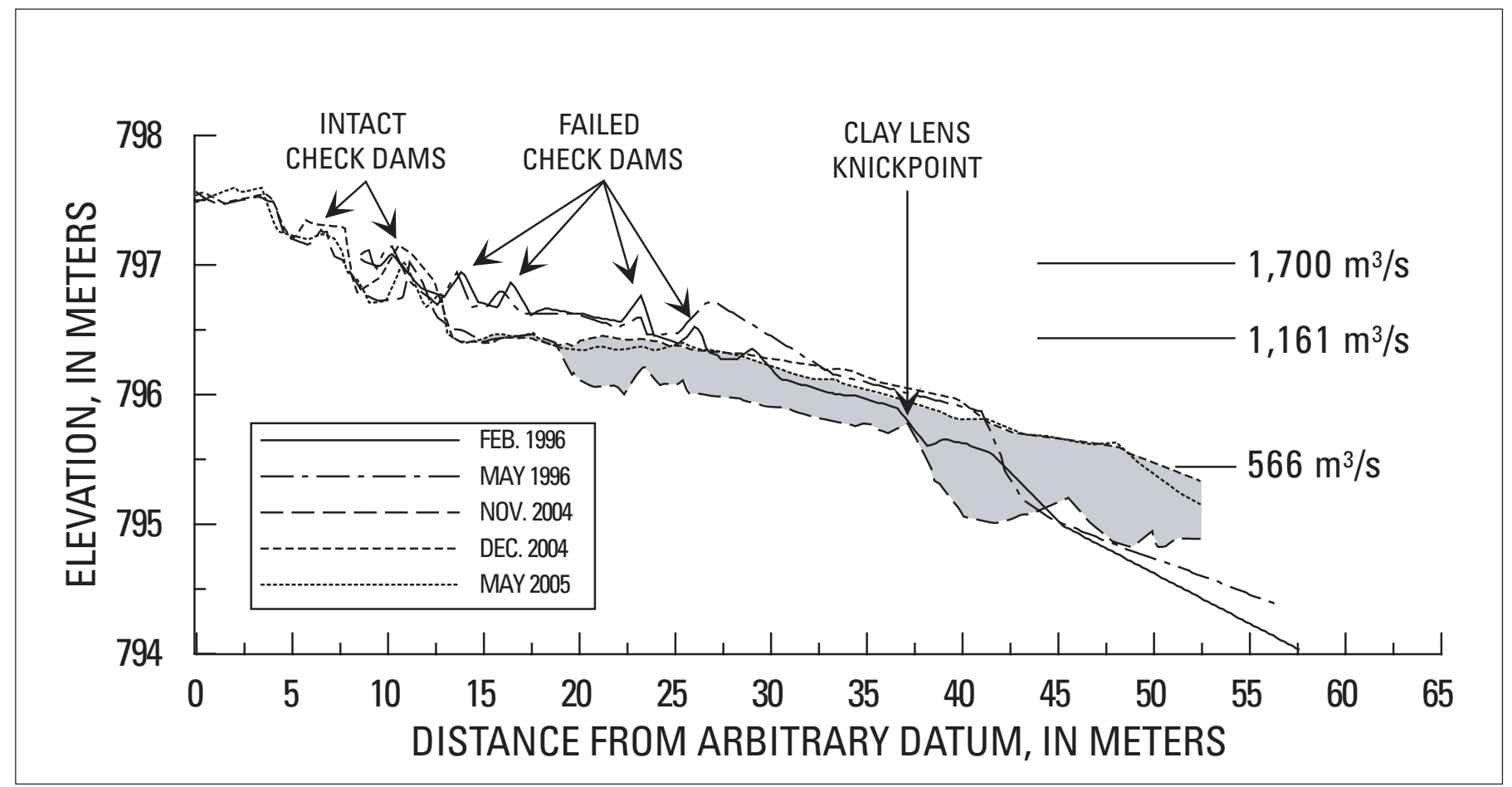

Figure 6. Pre- and post-flood centerline longitudinal profiles of the south gully mouth. The gray shaded area represents infilling of the gully mouth by the 2004 high-flow experiment (HFE). Variation in the longitudinal profile at elevations higher than those reached by the experimental flows is possibly the result of remediation efforts between 1997 and 2004 but also may represent inaccuracies in centerline positioning.


Figure 7. The south gully mouth viewed from the terminus at the Colorado River. $A$, The clay lens knickpoint as it appeared on November 20, 2004. B, Deposition in the gully bottom and erosion of the southern margin of the gully wall. Photographs by Amy Draut, U.S. Geological Survey. 
tion increase along the channel centerline following the 1996 controlled flood was $0.16 \mathrm{~m}$ compared to $0.34 \mathrm{~m}$ following the 2004 HFE (fig. 8). The sediment deposited in the south gully mouth by the 1996 controlled flood was still largely present in May 1999, after which the gully was incised $0.5 \mathrm{~m}$ in the 4-yr period before the $2004 \mathrm{HFE}$ (fig. 9). About $66.5 \mathrm{~m}^{3}$ of material was scoured from the $30 \mathrm{~m}$ length of the south gully mouth area (table 2), and four check dams present in the 1990s were entirely removed (fig. 6). As a result of renewed gullying between 1999 and 2004, the 2004 HFE flood peak extended about $10 \mathrm{~m}$ farther into the gully (fig. 8). Thus, the marked difference in depositional volume in the south gully mouth is likely the result of greater accommodation space available for deposition in 2004, rather than the result of differences in sediment supply or flood duration between the two flood experiments.

\section{Changes above the Elevations Reached by Experimental High Dam Releases}

Erosional patterns and knickpoint retreat for a 7-yr period are shown in figure 10. The downstream endpoints are located in each gully mouth and the upstream endpoints are located at the eastern edge of the playa-like catchment area (fig. 2). Interpreting the results is complicated by profile point spacing (table 1) and the removal or maintenance of erosion-control structures between topographic surveys (Dierker and Leap,
2006). This situation introduces considerable noise into the longitudinal profile because of small elevation changes (about $0.10-0.20 \mathrm{~m}$ ), which make it difficult to track localized erosion resulting from knickpoint retreat and breached or flanked erosion-control structures (fig. 10). Nonetheless, changes in profile gradient are useful for tracking longer term incision rates.

The gradient in both gullies steepened between February 1998 and February 2002 (table 3). In the subsequent 8 mo, between February and October 2002, there was a substantial erosional event documented by Pederson and others (2003). A new knickpoint with a clay lens cap developed in the south gully near the mouth, and a previously existing knickpoint advanced up the gully about $27 \mathrm{~m}$ (figs. $7 A$ and $10 B$ ). The gradient of the south gully increased from $0.037 \mathrm{~m}$ in January 2002 to $0.41 \mathrm{~m}$ in late September 2002. In the higher gradient north gully, the development of two small knickpoints resulted in a slight steepening of the gradient (fig. 10A).

The 2002 gullying in the lower gully reaches may have occurred during one storm. An unusual frontal system from the Pacific produced widespread rain and resulted in tributary debris flows to the Colorado River between the mouth of the Little Colorado River and Phantom Ranch on September 7, 2002 (Webb, 2003). On or around this date, flooding in nearby Lava Canyon and Carbon Creek caused hydraulic and geomorphic changes that increased the water-surface elevation of the pool upstream from Lava Canyon Rapid by $0.3-0.5 \mathrm{~m}$ (Hazel and others, 2006).

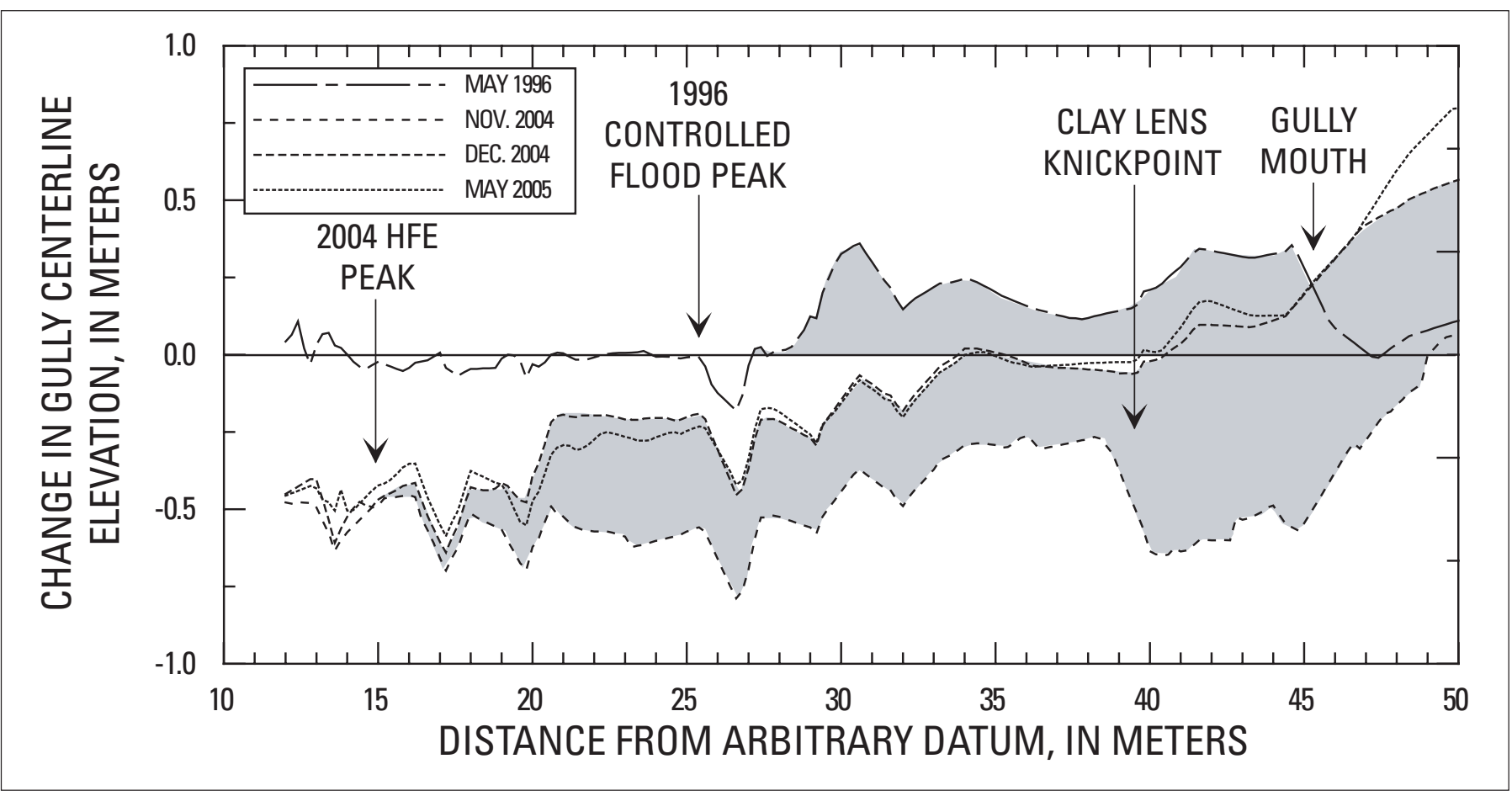

Figure 8. Pre- and post-flood changes along the centerline longitudinal profile of the south gully. Changes in gully elevation are with reference to a common datum (the solid horizontal line) defined by the pre-1996 flood condition. The gray shaded area represents infilling of the gully mouth by the 1996 controlled flood and 2004 high-flow experiment (HFE). Note that the 2004 HFE extended into the gully mouth about $10 \mathrm{~m}$ farther from the Colorado River than did the higher magnitude 1996 controlled flood. 
Figure 9. South gully mouth time series constructed from the average centerline elevation data in figure 8 . The February 1996 elevation equals 0 . Note that even though the deposition was two times greater in 2004 compared to 1996 , the base level of the gully mouth was not restored to the 1996 pre-flood condition.



During the 2-yr period following the 2002 erosional event, it appears that both north and south gullies were relatively stable. Deposition as a result of the 2004 HFE effectively lessened the gradient of the south gully from 0.38 to $0.33 \mathrm{~m}$, whereas the north gully was largely unaffected (table 3). The May 2005 survey found limited net change in the upper reaches, suggesting that little if any aeolian infilling occurred as a result of the presence of nearby river-level sandbars deposited by the 2004 HFE.

Although profile analyses are instructive for examination of gully incision, other measures are needed to examine gully widening that results from channel avulsion or breaching and flanking of check dams. In order to examine possible lateral erosion, the sidewalls of the arroyos and major tributaries were examined by this study. Specifically, cross sections established by a 1998 National Park Service survey were compared to cross-sectional data generated during November 2004 and May 2005 for the same locations (fig. 11). The results suggest that the upper reaches of both the north gully and the south gully and major tributaries were largely the same width and depth in 2004 as they were in 1998. It is unknown whether the sidewall stability measured between 1998 and 2004 was the result of remediation efforts such as armoring the sides of the gullies with rocks. Field observations during this study and repeat photography by Pederson and others $(2003,2006)$ indicate continued breaching and flanking of erosion-control structures from surface flow at other locations in the drainage network.

\section{Discussion and Conclusions}

This study was largely focused on documenting the amount and retention of sediment deposited in the mouths of the gullies draining the Palisades terraces by the 2004 HFE. When possible, the results were compared to previous studies of the site, particularly research associated with the 1996 controlled flood. The 2004 HFE inundated the lowermost terrace of the Palisades gully network and deposited a substantial volume $\left(24.7 \mathrm{~m}^{3}\right)$ of fine-grained sediment in the mouth of the south gully; however, the north gully was largely unaffected.

The amount of sediment deposited in the south gully mouth by the 2004 HFE was nearly two times larger than the 1996 controlled flood (table 2). Compared to 1996, the south gully had eroded to a greater depth before the 2004 HFE, and, as a result, the south gully had a larger accommodation space available for deposition during the 2004 event. Thus, the differences in the volume of sediment deposited by the two floods did not directly stem from differences in sediment supply or flood duration but rather greater space available for deposition in 2004. Additionally, the 2004 HFE deposit in the enlarged south gully mouth was largely retained in the 6 mo following the event (figs. 6 and 8). Infilling resulting from the 2004 HFE also affected the gradient of the gully. Compared to measurements taken in May 2005, the gradient of the south gully was less steep than it had been in February 1998, while the gradient of the north gully, in contrast, was more steep because it was unaffected by either flood.

The elevation of the gully mouth forms the effective base level for the drainage network. In both the south and the north gullies, most of the erosion was concentrated in the lowermost reaches near the gully mouths. Because infilling of gully mouths by experimental flows can establish a new higher effective base level, this may be an important finding. Hereford and others (1993) hypothesized that gully incision rates increased in the postdam era because gullies were eroding to the new, lower effective base level of the postdam Colorado 
Figure 10. Normalized longitudinal profiles. $A$, The 3.9-m drop of the north gully over a length of $85 \mathrm{~m}$. $B$, The 4-m drop of the south gully over a length of $122 \mathrm{~m}$. Data from October 2002, May 2004, and December 2004 are not shown for brevity. Small arrows indicate check dam locations surveyed by the National Park Service in 1998. The profile endpoints are shown in figure 2 .


Table 3. Lower and middle section gully slope gradients, February 1998-May 2005.

\begin{tabular}{llll}
\hline & Date & North gully & South gully \\
\hline February 1998 & .046 & .035 \\
February 2002 & .047 & .037 \\
September 2002 & .047 & .041 \\
November 2003 & .047 & .038 \\
November 2004 & .048 & .038 \\
December 2004 & .046 & .033 \\
May 2005 & .048 & .033 \\
\hline
\end{tabular}





Figure 11. Cross sections established by the National Park Service in January 1998. $A$, The lower south gully. $B$, The middle of the south gully. $C$, The upper south gully above the confluence with the first major tributary. $D$, The lower south tributary. $E$, The upper south tributary. $F$, The middle of the north gully. Data from December 2004 are not shown. There was no change in the upper part of the gullies in the 19 days between surveys. Note that all cross sections are above the elevation reached by the 2004 high-flow experiment. Cross sections are viewed in a down-gully direction. Locations are shown in figure 2. 
River shoreline deposits. Thompson and Potochnik (2000) revisited the base-level concept and proposed that deposition in gully mouths may provide a temporary base-level effect, resulting in reduced erosion upstream from gully mouths as well as providing a source of sand for aeolian deposition. This study found no discernible change in the upper drainage network of the two gullies at Palisades; however, the absence of noticeable change in the upper reaches could not be definitively linked to short-term base-level increases in the south gully mouth. Given the infrequency of high-flow events in the postdam era, any change in effective base level resulting from gully infilling is likely to be temporary. A local rainfall event will likely result in runoff sufficient to remove gully infilling, which is what occurred as the result of the 2002 storm discussed earlier. Nonetheless, despite the changes documented in the lower reach of the south gully, the uppermost reaches of both the north and south gullies appeared to be relatively stable, presenting little or no evidence of incision between 1998 and 2005.

Unfortunately, it was not possible to determine from this study whether or not gully mouth deposition or erosion-control structures were responsible for the channel stabilization. Differences in the types of data collected over time and changes in erosion-mitigation efforts that occurred between topographic surveys precluded accurate analysis of changes that may have occurred in the uppermost reaches of the gullies. To discern cause-and-effect relationship in the future, it is imperative that the same types of data be collected between surveys, maintenance of check dams be withheld, and more detailed local weather data be obtained. Future efforts to quantify and understand gully erosion in Grand Canyon National Park would be greatly enhanced by high-resolution survey mapping that encompasses the entire length of gully and catchment area, and accurately depicts gully width and depth.

\section{Acknowledgements}

This study was sponsored by the U.S. Geological Survey and Bureau of Reclamation through the Grand Canyon Monitoring and Research Center. We thank Amber Gaul, Sarah Goeking, Eric Kellerup, Keith Kohl, Meagan Polino, Albert Reichert, Tom Sabol, and Bob Tusso for their valued field assistance. Thanks also to Mike Breedlove for GIS support. Reviews provided by Joel Pederson and two other anonymous reviewers greatly improved the quality of this report.

\section{References}

Davis, P.A., 2004, Review of results and recommendations from the GCMRC 2000-2003 remote-sensing initiative for monitoring environmental resources within the Colorado River ecosystem: U.S. Geological Survey Open-File Report 2004-1206, 73 p.

Dierker, J., and Leap, L.M., 2006, Fiscal Year 2005 archaeological site monitoring and management activities along the Colorado River in Grand Canyon National Park: Draft report prepared by Grand Canyon National Park and Northern Arizona University, submitted to the Bureau of Reclamation, Upper Colorado Region, Salt Lake City, Utah, Grand Canyon National Park, River Corridor Monitoring Project, report 91, $151 \mathrm{p}$.

Draut, A.E., and Rubin, D.M., 2005, Measurements of wind, aeolian sand transport, and precipitation in the Colorado River corridor, Grand Canyon, Arizona; November 2003 to December 2004: U.S. Geological Survey Open-File Report 2005-1309, 70 p.

Draut, A.E., and Rubin, D.M., 2006, Measurements of wind, aeolian sand transport, and precipitation in the Colorado River corridor, Grand Canyon, Arizona; January 2005 to January 2006: U.S. Geological Survey Open-File Report 2006-1188, 88 p.

Draut, A.E., Rubin, D.M., Dierker, J.L., Fairley, H.C., Griffiths, R.E., Hazel, J.E., Jr., Hunter, R.E., Kohl, K., Leap, L.M., Nials, F.L., Topping, D.J., and Yeatts, M., 2005, Sedimentology and stratigraphy of the Palisades, Lower Comanche, and Arroyo Grande areas of the Colorado River corridor, Grand Canyon, Arizona: U.S. Geological Survey Scientific Investigations Report 2005-5072, 68 p., [http:// pubs.usgs.gov/sir/2005/5072, last accessed July 7, 2008].

Fairley, H.C., 2003, Changing river: time, culture, and the transformation of landscape in the Grand Canyon-a regional research design for the study of cultural resources along the Colorado River in lower Glen Canyon and Grand Canyon National Park, Arizona: Statistical Research, Inc., prepared for the U.S. Geological Survey, Grand Canyon Monitoring and Research Center, Flagstaff, Ariz., Technical Series 79, $179 \mathrm{p}$.

Fairley, H.C., Bungart, P.W., Coder, C.M., Huffman, J., Samples, T.L., and Balsom, J.R., 1994, The Grand Canyon river corridor survey project: Archaeological survey along the Colorado River between Glen Canyon Dam and Separation Canyon: Report prepared for Grand Canyon National Park Service, Cooperative Agreement No. 9AA-40-07920, 276 p. 
Grams, P., and Schmidt, J.C., 1999, Integration of photographic and topographic data to develop temporally and spatially rich records of sand bar change in the Point Hansbrough and Little Colorado River confluence study reaches: Final Report to Grand Canyon Monitoring and Research Center, Utah State University, Logan, Utah, 249 p.

Hazel, Joseph, E., Jr., Kaplinski, M., Manone, M., and Parnell, R., 2000, Monitoring arroyo erosion of pre-dam river terraces in the Colorado River ecosystem, 1996-1999, Grand Canyon National Park, Arizona: Draft Final Report to Grand Canyon Monitoring and Research Center, Northern Arizona University, Flagstaff, Ariz., 29 p.

Hazel, Joseph, E., Jr., Kaplinski, M., Parnell, R., Kohl, K., and Topping, D.J., 2006, Stage-Discharge Relations for the Colorado River in Glen, Marble, and Grand Canyons, Arizona: U.S. Geological Survey Open-File Report 2006-1243, 7 p.

Hereford, R., 1996, Map showing surficial geology and geomorphology of the Palisades Creek area, Grand Canyon National Park, Arizona: U.S. Geological Survey Miscellaneous Investigations Series Map I-2499, scale 1:2000 (with discussion).

Hereford, R., Fairley, H.C., Thompson, K.S., and Balsom, J.R., 1993, Surficial geology, geomorphology, and erosion of archaeologic sites along the Colorado River, eastern Grand Canyon, Grand Canyon National Park, Arizona: U.S. Geological Survey Open-File Report 93-517, 45 p., 4 pl.

Hereford, R., Thompson, K.S., Burke, K.J., and Fairley, H.C., 1996, Tributary debris fans and the late Holocene alluvial chronology of the Colorado River, eastern Grand Canyon, Arizona: Geological Society of America Bulletin, v. 108, no. 1, p. 3-19.

Huntoon, P.W., Billingsley, G.H., Breed, W.J., Sears, J.W., Ford, T.D., Clark, M.D., Babcock, R.S., and Brown, E.H., 1986, Geological map of the eastern part of Grand Canyon National Park, Arizona: Grand Canyon, Ariz., Grand Canyon Natural History Association, scale 1:62 500.

Leap, L.M., and Coder, C.M., 1995, Erosion control project at Palisades delta along the Colorado River corridor, Grand Canyon National Park: River Corridor Monitoring Project Report prepared for the Bureau of Reclamation, Salt Lake City, Utah, Grand Canyon National Park, River Corridor Monitoring Project, report no. 73.

Leap, L.M., Kunde, J.L., Hubbard, D.C., Andrews, N.B., Downum, C.E., Miller, A.R., and Balsom, J., 2000, Grand Canyon Monitoring Project 1992-1999; synthesis and annual report FY99: Report prepared by Grand Canyon National Park and Northern Arizona University, submitted to the Bureau of Reclamation, Upper Colorado Region, Salt Lake City, Utah, Grand Canyon National Park, River Corridor Monitoring Project, report no. 66.
Pederson, J.L., Peterson, P.A., Dierker, J.L., 2006, Gullying and erosion control at archaeological sites in Grand Canyon: Earth Surface Processes and Landforms, v. 31, p. 507-525.

Pederson, J.L., Peterson, P.A., Macfarlane, W.W., Gonzales, M.F., and Kohl, K., 2003, Mitigation, monitoring, and geomorphology related to gully erosion of cultural sites in Grand Canyon: Logan, Utah, Utah State University, Report to Grand Canyon Monitoring and Research Center, Nov. 2003, $243 \mathrm{p}$.

Schmidt, J. C., and Graf, J.B., 1990, Aggradation and degradation of alluvial sand deposits, 1965 to 1986, Colorado River, Grand Canyon National Park, Arizona: U.S. Geological Survey Professional Paper 1493, 74 p.

Thompson, K.S., and Potochnik, A.R., 2000, Development of a geomorphic model to predict erosion of pre-dam Colorado river terraces containing archaeological resources: SWCA Cultural Resources Report No. 99-257, prepared for Grand Canyon Monitoring and Research Center by SWCA, Inc., Environmental Consultants, Flagstaff, Ariz.

Topping, D.J., Rubin, D.M., Schmidt, J.C., Hazel, J.E., Jr., Melis, T.S., Wright, S.A., Kaplinski, M., Draut, A.E., and Breedlove, M.J., 2006, Comparison of sediment-transport and bar-response results from the 1996 and 2004 controlledflood experiments on the Colorado River in Grand Canyon: CD-ROM Proceedings of the Eighth Federal Inter-Agency Sedimentation Conference, Reno, Nev., April 2-6, 2006, ISBN 0-9779007-1-1.

U.S. Department of the Interior, 1995, Operation of Glen Canyon Dam Final Environmental Impact Statement, Colorado River Storage Project, Coconino County, Arizona: Salt Lake City, Utah, Bureau of Reclamation, Upper Colorado Regional Office, 337 p.

Webb, R.H., 2003, 2002 Debris flows and floods in Grand Canyon: Boatman's Quarterly Review, v. 15, no. 4., [http:// www.gcrg.org/bqr/15-4/debris.html, last accessed July 28, 2008].

Webb, R.H., Schmidt, J.C., Marzolf, G.R., and Valdez, R.A., eds., The controlled flood in Grand Canyon: scientific experiment and management demonstration: Washington, D.C., American Geophysical Union, Geophysical Monograph Series, v. 110, $367 \mathrm{p}$.

Yeatts, M., 1996, High elevation sand deposition and retention from the 1996 spike flow: an assessment for cultural resources stabilization: Report on file at the Grand Canyon Monitoring and Research Center, Flagstaff, Ariz., 32 p.

Yeatts, M., 1998, High elevation sand retention following the 1996 spike: Report on file at the Grand Canyon Monitoring and Research Center, Flagstaff, Ariz., 15 p. 
This page intentionally left blank 
